\title{
Dynamic modeling and control structure design of an experimental fuel processor
}

\author{
Shi-Tin Lin ${ }^{\mathrm{a}}$, Yih-Hang Chen ${ }^{\mathrm{b}}$, Cheng-Ching Yu${ }^{\mathrm{a}, *}$, Yen-Chun Liu ${ }^{\mathrm{c}}$, Chiou-Hwang Lee \\ a Department of Chemical Engineering, National Taiwan University, Taipei 106-17, Taiwan \\ ${ }^{\mathrm{b}}$ Advanced Energy Technology Laboratory, Industrial Technology Research Institute, Hsinchu 300, Taiwan \\ ${ }^{\mathrm{c}}$ Union Chemical Laboratory, Industrial Technology Research Institute, Hsinchu 300, Taiwan
}

Received 7 January 2005; received in revised form 13 June 2005; accepted 20 June 2005

Available online 15 August 2005

\begin{abstract}
In this work, a dynamic model is developed to describe an experimental methane fuel processor which is intended to provide hydrogen for a proton exchange membrane fuel cell (PEMFC) for power generation $(2-3 \mathrm{kWe})$. First-principle reactor models were constructed to describe dynamic behavior for a series of reactions, starting from reforming (SR/ATR), to high- and lowtemperature water gas shift reactions (HTS/LTS), and then to preferential oxidation (PROX) reactions. A systematic procedure is proposed to identify dynamic-relevant model parameters, and reasonable behavior description can be obtained. Finally, two plantwide control structures, on-demand structure and on-supply structure are designed and the performance of these two control structures is evaluated for load disturbance rejection. The results indicate that the on-demand control structure gives a rapid transition to different power demands.

(C) 2005 International Association for Hydrogen Energy. Published by Elsevier Ltd. All rights reserved.
\end{abstract}

Keywords: Proton exchange membrane fuel cell; Fuel processor; Process dynamics; Plantwide control; Autothermal reforming; Steam reforming

\section{Introduction}

Fuel cell systems offer high potential for efficiency and reduced emissions in power generation [1]. The proton exchange membrane fuel cell (PEMFC) is one of the most popular fuel cell systems in which fuels such as methanol or methane are converted to hydrogen-rich syn-gas in a reformer and which is subsequently used in the fuel cell stack. In addition to the reformer, a series of $\mathrm{CO}$ reducing steps, water gas shift reactions and preferential oxidation reactions were taken to keep CO concentrations below $100 \mathrm{ppm}$ before the syn-gas enters the cell stack. This combination

\footnotetext{
* Corresponding author. Tel.: +88623365 1759; fax: +886233663037 .

E-mail address: ccyu@ntu.edu.tw (C.-C. Yu).
}

constitutes the entire fuel processor [2]. A dynamic model is essential for the fuel processor operation for the following reasons: (1) discriminating control system design for improved load rejection, and (2) evaluating start-up strategies for fast start-up.

Extensive literature has examined various aspects of fuel processor systems for hydrogen-rich syn-gas production, which include overviews of the fuel processing technology [3-6], in which the reforming technology of hydrocarbon fuels is still the major focus. Steady-state simulations are often performed for sensitivity analyses in the design and operation phases of the fuel processor [7-10]. Studies on dynamic behavior of the fuel processor have received some attention lately, and typically the relationships between feed conditions and dynamic responses were explored in $[11,12]$. The start-up dynamics was explored in [13] in order to devise a more efficient start-up strategy. Literature 


\begin{tabular}{|c|c|c|c|}
\hline \multicolumn{4}{|c|}{ Nomenclature } \\
\hline$C_{P}$ & heat capacity of the gas $\left(\mathrm{kJ} \mathrm{mol}^{-1} \mathrm{~K}^{-1}\right)$ & $T_{\mathrm{A}}$ & surrounding temperature $(\mathrm{K})$ \\
\hline$C_{P, \mathrm{~S}}$ & heat capacity of the carrier $\left(\mathrm{kJ} \mathrm{g}^{-1} \mathrm{~K}^{-1}\right)$ & $T_{\mathrm{f}}$ & temperature of the feed $(\mathrm{K})$ \\
\hline$C_{P \mathrm{~W}}$ & heat capacity of the metal reforming reactor & $T_{\text {in }}$ & inlet temperature of the reformer $(\mathrm{K})$ \\
\hline & wall $\left(\mathrm{kJ} \mathrm{g}^{-1} \mathrm{~K}^{-1}\right)$ & $T_{\mathrm{H} 1}$ & inlet temperature of the HTS1 (K) \\
\hline$D_{\mathrm{I}}$ & inner diameter of the reactor $(\mathrm{cm})$ & $T_{\mathrm{H} 2}$ & inlet temperature of the HTS2 (K) \\
\hline$D_{\mathrm{o}}$ & outer diameter of the reforming reactor $(\mathrm{cm})$ & $T_{\mathrm{L}}$ & inlet temperature of the LTS (K) \\
\hline$F$ & total molar flow rate $\left(\mathrm{mol} \mathrm{min}^{-1}\right)$ & $T_{\mathrm{P}}$ & inlet temperature of the PROX $(\mathrm{K})$ \\
\hline$k_{\text {cond }}$ & $\begin{array}{l}\text { thermal conductivity of the metal reactor wall } \\
\left(\mathrm{kJ} \mathrm{min} \min ^{-1} \mathrm{~cm}^{-1} \mathrm{~K}^{-1}\right)\end{array}$ & $U$ & $\begin{array}{l}\text { heat transfer coefficient }\left(\mathrm{kJ} \mathrm{min}^{-1} \mathrm{~cm}^{-2}\right. \\
\left.\mathrm{K}^{-1}\right)\end{array}$ \\
\hline$m_{\mathrm{W}}$ & weight of the reforming reactor $(\mathrm{g})$ & $W_{\mathrm{S}}$ & carrier weight $(\mathrm{g})$ \\
\hline$M_{\mathrm{F}}$ & molar holdup of the burner (mol) & $W_{\text {cat }}$ & catalyst weight (g) \\
\hline$P$ & pressure (atm) & $y$ & mole fraction \\
\hline$Q_{\mathrm{F}}$ & heat input for preheating $(\mathrm{kJ} \mathrm{min}-1)$ & $\Delta H_{\mathrm{R}}$ & heat of reaction of reaction $\left(\mathrm{kJ} \mathrm{mol}^{-1}\right)$ \\
\hline$r$ & rate of reaction & $\rho$ & density of the carrier $\left(\mathrm{ml} \mathrm{g}^{-1}\right)$ \\
\hline$T$ & reaction temperature $(\mathrm{K})$ & $\rho_{\mathrm{av}}$ & average density of the gas in the reforming \\
\hline$T_{\mathrm{W}}$ & reactor wall temperature $(\mathrm{K})$ & & reactor $\left(\mathrm{mol} \mathrm{ml}^{-1}\right)$ \\
\hline$V_{\mathrm{R}}$ & volume of the gas $(\mathrm{ml})$ & $v$ & stoichiometric coefficient of the reaction \\
\hline
\end{tabular}

for dynamics and control of fuel processor is scattered in conference proceedings with only a handful of journal papers.

The objective of this work is to construct a dynamic model for a methane fuel processor and different control structures can be evaluated based on the disturbance rejection capability. The remainder of this paper is organized as follows. Section 2 describes the process and dynamic modeling of the fuel processor. Sensitivities of operating parameters are explored in Section 3, followed by control structure design and evaluation in Section 4. The conclusion is drawn in Section 5 .

\section{Process studied}

\subsection{Reaction kinetics}

A fuel processor consists of several reactors, heat exchangers and cooling devices (direct waters injection). It can be viewed as a small chemical plant with a series of reactors for reforming and gas cleaning. Fig. 1 shows the experimental setup of the fuel processor in the facility of Union Chemical Laboratory (UCL) of the Industrial Technology Research Institute (ITRI); the corresponding dimensions are also given. The experimental fuel processor is simplified to a reformer, a burner, three water gas shift reactors and a preferential oxidation reactor for the modeling purpose (Fig. 2). Methane, air and water were fed into the reformer to carry out autothermal reforming (ATR). The reformer was integrated with a burner which had the function of preheating the feed and supplying heat needed for the reactions. Table 1 shows the reactions that occurred in the reformer
[7], where $r_{1}$ is an endothermic reaction while $r_{2}$ and $r_{3}$ are exothermic reactions.

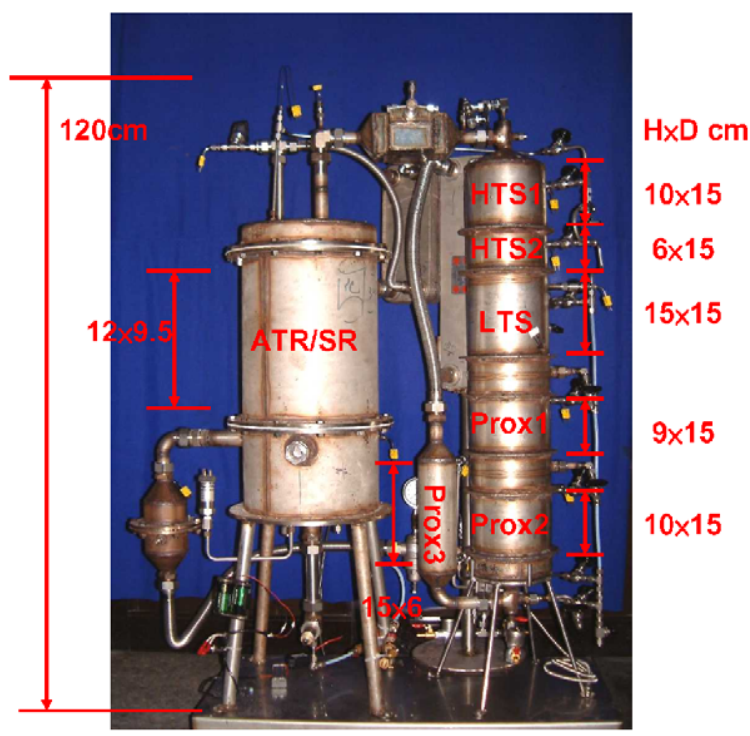

Fig. 1. Experimental fuel processor and corresponding dimensions.

The effluent of the reformer is passed through a feedeffluent heat exchanger, followed by a liquid water injection to cool the temperature down to the desired HTS1 inlet temperature. In fact, the hydrogen-rich syn-gas goes through a series of reactors to perform the water gas shift reaction (HTS1, HTS2 and LTS) in which CO was removed to meet the specification. Because of the monotonically decreasing arrangement of the temperature profile for the water gas 


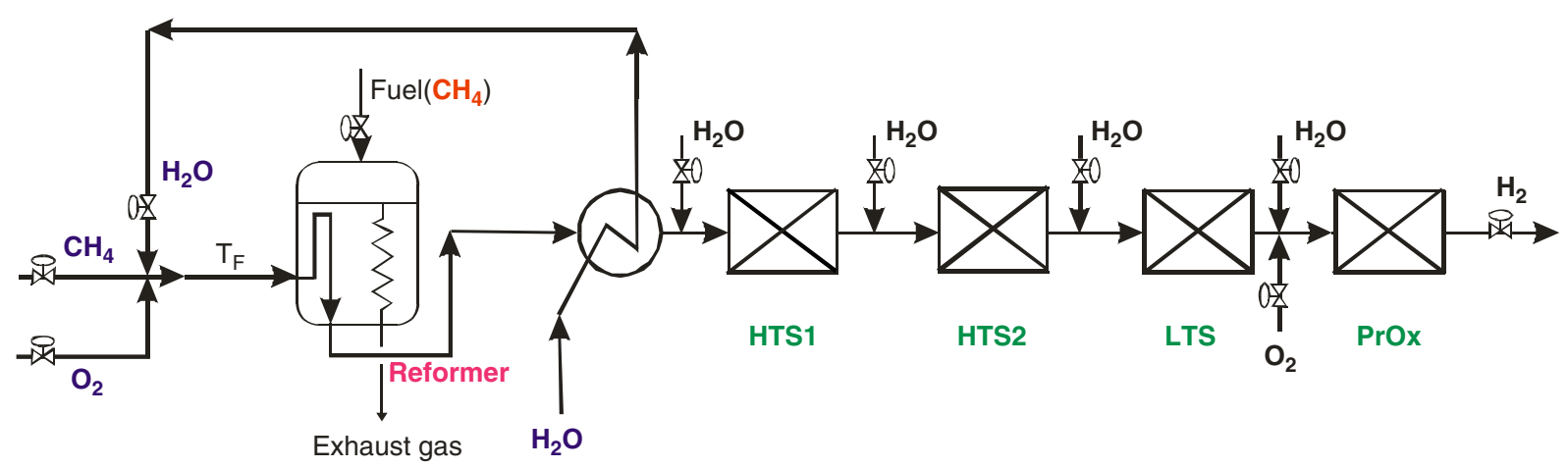

Fig. 2. Process configuration of the experimental fuel processor.

Table 1

Reaction rate expressions and parameter values for the fuel processor system

\begin{tabular}{|c|c|c|c|}
\hline Reactor & Reaction & Kinetics & $\Delta H_{\mathrm{R}}\left(\mathrm{kJ} \mathrm{mol}^{-1}\right)$ \\
\hline \multirow[t]{2}{*}{ ATR } & $\mathrm{CH}_{4}+\mathrm{H}_{2} \mathrm{O} \Leftrightarrow \mathrm{CO}+3 \mathrm{H}_{2}$ & $r_{1}=\frac{k_{1} P_{\mathrm{CH}_{4}} P_{\mathrm{H}_{2} \mathrm{O}}-k_{1}^{\prime} P_{\mathrm{CO}} P_{\mathrm{H}_{2}}^{3}}{P_{\mathrm{H}_{2}}^{2.5}\left(\alpha_{1}\right)^{2}}$ & 206 \\
\hline & $\begin{array}{l}\mathrm{CO}+\mathrm{H}_{2} \mathrm{O} \Leftrightarrow \mathrm{CO}_{2}+\mathrm{H}_{2} \\
\mathrm{CH}_{4}+2 \mathrm{O}_{2} \Rightarrow \mathrm{CO}_{2}+2 \mathrm{H}\end{array}$ & $\begin{array}{l}r_{2}=\frac{k_{2} P_{\mathrm{CO}} P_{\mathrm{H}_{2} \mathrm{O}}-k_{2}^{\prime} P_{\mathrm{CO}_{2}} P_{\mathrm{H}_{2}}}{P_{\mathrm{H}_{2}}\left(\alpha_{1}\right)^{2}} \\
r_{3}=\frac{k_{3 \mathrm{a}} P_{\mathrm{CH}_{4}} P_{\mathrm{O}_{2}}}{\left(\alpha_{2}\right)^{2}}+\frac{k_{3 \mathrm{~b}} P_{\mathrm{CH}_{4}} P_{\mathrm{O}_{2}}}{\left(\alpha_{2}\right)}\end{array}$ & $\begin{array}{l}-41.2 \\
810\end{array}$ \\
\hline $\begin{array}{l}\text { HTS1 } \\
\text { HTS2 }\end{array}$ & $\mathrm{CO}+\mathrm{H}_{2} \mathrm{O} \Leftrightarrow \mathrm{CO}_{2}+\mathrm{H}_{2}$ & $r_{\mathrm{HTS}}=k_{\mathrm{H}} P_{\mathrm{CO}} P_{\mathrm{H}_{2} \mathrm{O}}-k_{\mathrm{H}}^{\prime} P_{\mathrm{H}_{2}} P_{\mathrm{CO}_{2}}$ & -41.2 \\
\hline LTS & $\mathrm{CO}+\mathrm{H}_{2} \mathrm{O} \Leftrightarrow \mathrm{CO}_{2}+\mathrm{H}_{2}$ & $r_{\mathrm{LTS}}=k_{\mathrm{L}} P_{\mathrm{CO}} P_{\mathrm{H}_{2} \mathrm{O}}-k_{\mathrm{L}}^{\prime} P_{\mathrm{H}_{2}} P_{\mathrm{CO}_{2}}$ & -41.2 \\
\hline \multirow[t]{2}{*}{ PROX } & $\mathrm{CO}+\frac{1}{2} \mathrm{O}_{2} \Rightarrow \mathrm{CO}_{2}$ & $r_{\mathrm{PROX} 1}=k_{\mathrm{CO}} P_{\mathrm{CO}}$ & -283 \\
\hline & $\mathrm{H}_{2}+\frac{1}{2} \mathrm{O}_{2} \Rightarrow \mathrm{H}_{2} \mathrm{O}$ & $r_{\mathrm{PROX} 2}=1.5 r_{\mathrm{CO}}$ & -243 \\
\hline
\end{tabular}

$\alpha_{1}=\left(1+K_{\mathrm{CO}} P_{\mathrm{CO}}+K_{\mathrm{H}_{2}} P_{\mathrm{H}_{2}}+K_{\mathrm{CH}_{4}} P_{\mathrm{CH}_{4}}+K_{\mathrm{H}_{2} \mathrm{O}} P_{\mathrm{H}_{2} \mathrm{O}} / P_{\mathrm{H}_{2}}\right), \alpha_{2}=\left(1+K_{\mathrm{CH}_{4}}^{\mathrm{OX}} P_{\mathrm{CH}_{4}}+K_{\mathrm{O}_{2}} \mathrm{OX}_{\mathrm{O}_{2}}\right)$, with $K_{\mathrm{CH}_{4}}=6.65 \times 10^{-4} \mathrm{e}^{\left(4607 / T_{n}\right)}$, $K_{\mathrm{CO}}=8.23 \times 10^{-5} \mathrm{e}^{\left(8504 / T_{n}\right)}, K_{\mathrm{H}_{2}}=6.12 \times 10^{-9} \mathrm{e}^{\left(9971 / T_{n}\right)}, K_{\mathrm{H}_{2} \mathrm{O}}=1.77 \times 10^{5} \mathrm{e}^{\left(-10669 / T_{n}\right)}, K_{\mathrm{CH}_{4}}^{\mathrm{OX}}=1.26 \times 10^{-1} \mathrm{e}^{\left(3284 / T_{n}\right)}$ and $K_{\mathrm{O}_{2}}^{\mathrm{OX}}=7.87 \times 10^{-7} \mathrm{e}^{\left(11162 / T_{n}\right)}$.

shift reactors, liquid water injection devices were installed between reactors. The reaction that takes place in the water gas shift reactors is the same as $r_{2}$ except that a different type of catalyst is used (shown in Table 1). In this work, we use the rate expression of Choi and Stenger [9] for kinetics expression. Corresponding rate constants obtained from the regression of the steady-state data are shown in Table 2.

Generally, the CO concentration out of the LTS was still too high, so the preferential oxidation reaction (PROX) was performed. An oxygen $\left(\mathrm{O}_{2}\right)$ injection device was installed at the inlet of PROX, and then $\mathrm{CO}$ was further oxidized to $\mathrm{CO}_{2}$, while, simultaneously, $\mathrm{H}_{2}$ was oxidized to $\mathrm{H}_{2} \mathrm{O}$. Note that a $\mathrm{H}_{2} \mathrm{O}$ stream is injected right before the PROX to bring the temperature from $241^{\circ} \mathrm{C}$ (LTS outlet) down to $150^{\circ} \mathrm{C}$ (PROX inlet). Both reactions in the PROX are exothermic reactions. The rate expressions are given in Table 1 and corresponding parameter values are shown in Table 2 for the entire fuel processor.
Table 2

Regression reaction kinetic data for experimental fuel processor

\begin{tabular}{llll}
\hline Reactor & Reaction & $\begin{array}{l}\text { Pre-exponential } \\
\text { factor } a_{0}\end{array}$ & $\begin{array}{l}\text { Activation } \\
\text { energy } \\
\left(\mathrm{kJ} \mathrm{mol}^{-1}\right)\end{array}$ \\
\hline ATR & $\mathrm{r}(1)$, forward $k_{1}$ & $6.32 \times 10^{16}$ & 240.1 \\
& $\mathrm{r}(1)$, reverse $k_{1}^{\prime}$ & $1.759 \times 10^{3}$ & 17.0 \\
& $\mathrm{r}(2)$, forward $k_{2}$ & $2.77 \times 10^{6}$ & 67.1 \\
& $\mathrm{r}(3)$, forward $k_{3 \mathrm{a}}$ & $1.56 \times 10^{8}$ & 86.0 \\
& $\mathrm{r}(3)$, forward $k_{3 \mathrm{~b}}$ & $1.31 \times 10^{8}$ & 86.0 \\
HTS & $\mathrm{r}_{\text {HTS }}$, forward $k_{\mathrm{H}}$ & $9.886 \times 10^{5}$ & 47.4 \\
& $\mathrm{r}_{\text {HTS }}$, reverse $k_{\mathrm{H}}^{\prime}$ & $1.32 \times 10^{-2}$ & 38.1 \\
LTS & $\mathrm{r}_{\text {LTS }}$, forward $k_{\mathrm{L}}$ & $1.285 \times 10^{6}$ & 47.4 \\
& $\mathrm{r}_{\text {LTS }}$, reverse $k_{\mathrm{L}}^{\prime}$ & $1.32 \times 10^{-2}$ & 38.1 \\
PROX & $\mathrm{r}_{\text {PROX }}$, forward $k_{\text {PROX }}$ & $1.34 \times 10^{4}$ & 8.3 \\
\hline
\end{tabular}




\subsection{Dynamic modeling}

Homogeneous reactor models were set up to describe the dynamic behavior of the experimental fuel processor. The assumptions and simplifications made for the system are:

(1) Constant pressure in the fuel processor (1 bar).

(2) Ideal gas behavior for each component.

(3) Temperature of the vapor and solid phase being the same.

(4) Thermal capacitance of the gas in the reactor negligible as compared to that of the solid catalyst and carrier.

(5) Negligible heat loss for the HTS1, HTS2, LTS and PROX reactors.

Partial differential equations describing the energy and mass balances are lumped into $N$ sections using the honeycomb carrier weight $\left(W_{\mathrm{S}}\right)$ as the independent variable (Note that this also applies to the catalyst weight $W_{\text {cat }}$, because it is assumed that the catalyst is distributed uniformly throughout the carrier). Thus, we have $N$ ordinary differential equations instead of one partial differential equation for each component balance [15]. Consider the $n$th section in the axial direction.

The energy balance of the reformer can be expressed as

$$
\begin{aligned}
C_{P, \mathrm{~S}} W_{\mathrm{S}, n} \frac{\mathrm{d} T_{n}}{\mathrm{~d} t}= & F_{n-1} C_{P, n-1} T_{n-1}-F_{n} C_{P, n} T_{n} \\
& -W_{\mathrm{cat}, n} \sum_{j} \Delta H_{\mathrm{R}, j}^{0} r_{n, j} \\
& -4 U\left(T_{n}-T_{\mathrm{W}, n}\right) W_{\mathrm{S}, n} /\left(\rho_{\mathrm{S}} D_{\mathrm{I}}\right) .
\end{aligned}
$$

Here $C_{P, S}$ is the heat capacity of the carrier, $W_{\mathrm{S}, n}$ denotes the weight of the carrier, and $n$ represents the $n$th lump. $T_{n}$ and $T_{\mathrm{w}, n}$ represent the reaction temperature and reactor wall temperature in the $n$th lump, respectively. $F_{n}$ is the total molar flow rate at the $n$th lump $C_{P, n}$ is the heat capacity of the gas in the $n$th lump and $W_{\text {cat }, n}$ is the weight of the catalyst in the $n$th lump. $r_{n, j}$ is the reaction rate of the $j$ th reaction at the $n$th section, $\Delta H_{\mathrm{R}, j}$ is the heat of reaction for the $j$ th reaction, $U$ is the overall heat transfer coefficient, $D_{\text {I }}$ is the inner diameter of the reactor and $\rho_{\mathrm{S}}$ is the density of the carrier. The component material balance for the $i$ th composition becomes

$$
\begin{aligned}
\rho_{\mathrm{av}} V_{\mathrm{R}, n} \frac{\mathrm{d} y_{n, i}}{\mathrm{~d} t}= & F_{n-1} y_{n-1, i}-F_{n} y_{n, i} \\
& +W_{\mathrm{cat}, n} \sum_{j} v_{i j} r_{n, j},
\end{aligned}
$$

where $\rho_{\mathrm{av}}$ is the averaged density of the gas in the reforming reactor. $V_{\mathrm{R}, n}$ is the volume of the gas in the $n$th lump of the reformer, $v_{i, j}$ is the stoichiometric coefficient of the $i$ th component under $j$ th reaction and $y_{n, i}$ is the mole fraction of the $i$ th component in the $n$th lump.
The reactor metal wall temperature is also lumped as follows:

$$
\begin{aligned}
m_{\mathrm{W}, n} C_{P \mathrm{~W}, n} \frac{\mathrm{d} T_{\mathrm{W}, n}}{\mathrm{~d} t}= & k_{\text {cond }} A\left(T_{\mathrm{W}, n-1}-T_{\mathrm{W}, n}\right) \\
& +4 U\left(T_{n}-T_{\mathrm{W}, n}\right) W_{\mathrm{S}, n} /\left(\rho D_{\mathrm{I}}\right) \\
& +4 U\left(T_{\mathrm{A}}-T_{\mathrm{W}, n}\right) W_{\mathrm{S}, n} /\left(\rho D_{\mathrm{O}}\right),
\end{aligned}
$$

where $m_{\mathrm{W}, n}$ is the weight of the metal reactor wall in the $n$th lump, $C_{P \mathrm{w}, n}$ is the heat capacity of the metal reactor wall, $k_{\text {cond }}$ is the thermal conductivity of the reactor wall and $D_{\mathrm{o}}$ is the outer diameter of the reforming reactor. $T_{\mathrm{A}}$ represents the ambient temperature.

The inlet of the reformer is heated by a burner and the temperature can be expressed as

$C_{P, \text { avg }} M_{\mathrm{F}} \frac{\mathrm{d} T_{\mathrm{in}}}{\mathrm{d} t}=Q_{\mathrm{F}}+F \sum y_{i} C_{P, i}\left(T_{\mathrm{f}}-T_{\mathrm{in}}\right)$,

where $C_{P}$ is the heat capacity of the feed and $M_{\mathrm{F}}$ is the molar holdup of the burner. $Q_{\mathrm{F}}$ is the heat needed for preheating and $T_{\mathrm{f}}$ is the temperature of the fresh feed, which is assumed to be $25^{\circ} \mathrm{C}$.

The relationship between the reactor inlet temperature $T_{\text {in }}$ ( $T_{\mathrm{O}}$ is the lumped notation) and the reactor wall temperature at the inlet ( $T_{\mathrm{W}, \mathrm{o}}$ is the lumped notation) is established from a regression model of the form $T_{\mathrm{W}, \mathrm{o}}=1.65 T_{\mathrm{O}}-864$. The energy balance equations describing the burner provide the inlet conditions for the reformer gas and metal wall temperatures. The composition and temperature profiles can be evaluated by solving these ordinary differential equations.

Similarly, the equations describing water gas shift reactor and PROX can be derived. The energy balance equation becomes

$$
\begin{aligned}
C_{P, \mathrm{~S}} W_{\mathrm{S}, n}\left(\frac{\mathrm{d} T}{\mathrm{~d} t}\right)= & F_{n-1} C_{P, n-1} T_{n-1}-F_{n} C_{P, n} T_{n} \\
& -W_{\mathrm{cat}, n} \sum_{j} \Delta H_{\mathrm{R}, j}^{0} v_{i j} r_{n, j},
\end{aligned}
$$

and the component material balance equation is

$$
\begin{aligned}
\rho_{\mathrm{av}} V_{\mathrm{R}, n} \frac{\mathrm{d} y_{n, i}}{\mathrm{~d} t}= & F_{n-1} y_{n-1, i}-F_{n} y_{n, i} \\
& +W_{\text {cat }, n} \sum_{j} v_{i j} r_{n, j} .
\end{aligned}
$$

The modeling equations of the HTS1, HTS2, LTS and PROX were assumed to be adiabatic and they were simpler than the modeling equation of the reformer.

The rate expressions of the reactions $\left(r_{j}\right)$ that take place in the fuel processor were obtained form the regression of the experimental data as shown in Table 1 and the parameter values are given in Table 2. Table 3 summarizes the steadystate operating condition with a $\mathrm{H}_{2} \mathrm{O} / \mathrm{CH}_{4}$ feed ratio of $1.45, \mathrm{O}_{2} / \mathrm{CH}_{4}$ feed ratio of 0.45 while the reformer inlet temperature was set to $717^{\circ} \mathrm{C}$ (high temperature constraint for both the material and catalyst of the reformer [14]). This 
Table 3

Steady-state operating condition $\left(\mathrm{mol} \mathrm{min}^{-1}\right)$ for fuel processor system

\begin{tabular}{|c|c|c|c|c|c|c|c|c|c|}
\hline & $\left({ }^{\circ} \mathrm{C}\right)$ & $T$ & $\mathrm{CH}_{4}$ & $\mathrm{H}_{2} \mathrm{O}$ & $\mathrm{CO}$ & $\mathrm{CO}_{2}$ & $\mathrm{O}_{2}$ & $\mathrm{H}_{2}$ & $\mathrm{~N}_{2}$ \\
\hline \multirow[t]{2}{*}{ ATR } & Inlet & 717 & 0.480 & 0.696 & 0 & 0 & 0.216 & 0 & 0.812 \\
\hline & Outlet & 650 & 0.015 & 0.413 & 0.274 & 0.191 & 0.03 & 1.21 & 0.812 \\
\hline \multicolumn{2}{|c|}{ Cooling (ATR) } & - & - & 0.486 & - & - & - & - & - \\
\hline \multirow[t]{2}{*}{ HTS1 } & Inlet & 350 & 0.015 & 0.898 & 0.274 & 0.191 & 0.03 & 1.210 & 0.812 \\
\hline & Outlet & 402 & 0.015 & 0.710 & 0.081 & 0.390 & 0.03 & 1.410 & 0.812 \\
\hline \multicolumn{2}{|c|}{ Cooling (HTS1) } & - & - & 0.200 & - & - & - & - & - \\
\hline \multirow[t]{2}{*}{ HTS2 } & Inlet & 317 & 0.015 & 0.910 & 0.081 & 0.390 & 0.03 & 1.410 & 0.812 \\
\hline & Outlet & 322 & 0.015 & 0.880 & 0.059 & 0.410 & 0.03 & 1.427 & 0.812 \\
\hline \multicolumn{2}{|c|}{ Cooling (HTS2) } & - & - & 0.220 & - & - & - & - & - \\
\hline \multirow[t]{2}{*}{ LTS } & Inlet & 237 & 0.015 & 1.110 & 0.059 & 0.410 & 0.03 & 1.427 & 0.812 \\
\hline & Outlet & 241 & 0.015 & 1.090 & 0.043 & 0.420 & 0.03 & 1.440 & 0.812 \\
\hline \multicolumn{2}{|c|}{ Cooling (LTS) } & - & - & 0.270 & - & - & - & - & - \\
\hline \multirow[t]{2}{*}{ PROX } & Inlet & 150 & 0.015 & 1.360 & 0.043 & 0.420 & 0.03 & 1.440 & 0.812 \\
\hline & Outlet & 320 & 0.015 & 1.360 & $1.3 \times 10^{-4}$ & 0.470 & 0.011 & 1.380 & 0.812 \\
\hline
\end{tabular}
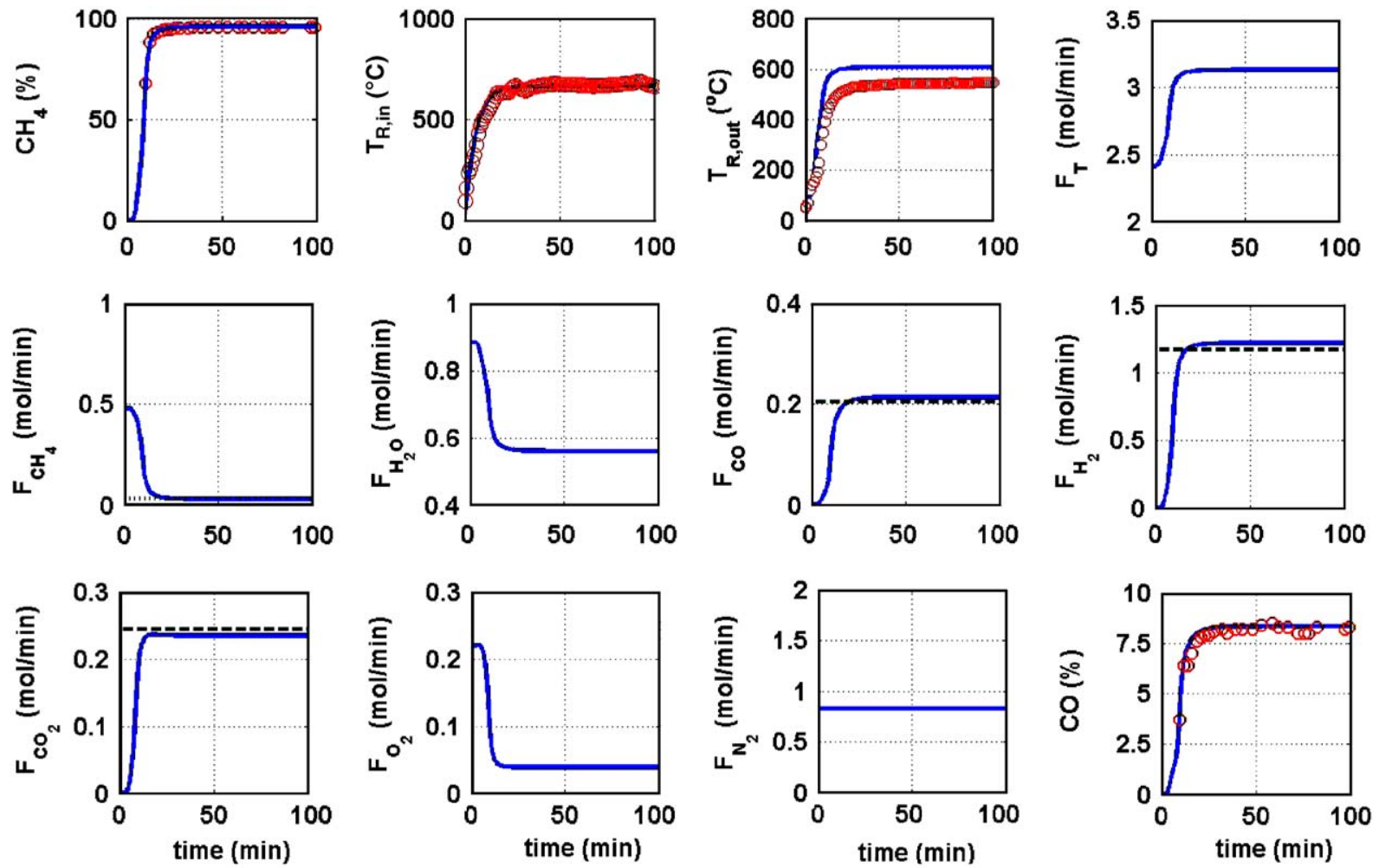

Fig. 3. Start-up dynamics of the ATR pathway: simulation (solid line) and experimental data (open circle) at the outlet of the ATR reactor. 
Table 4

Catalyst weight, heat capacities and dimensions for the reactors

\begin{tabular}{|c|c|c|c|c|c|c|}
\hline & $\begin{array}{l}W_{\text {cat }} \\
(\mathrm{g})\end{array}$ & $\begin{array}{l}W_{\mathrm{S}} \\
(\mathrm{g})\end{array}$ & $\begin{array}{l}C_{P} \\
\left(\mathrm{~J} \mathrm{~g}^{-1} \mathrm{~K}^{-1}\right)\end{array}$ & $\begin{array}{l}\text { Length } \\
(\mathrm{cm})\end{array}$ & $\begin{array}{l}\text { Diameter } \\
(\mathrm{cm})\end{array}$ & $\begin{array}{l}\text { Carrier volume } \\
(\mathrm{ml})\end{array}$ \\
\hline ATR & 80 & 3033.6 & 0.221 & 12.0 & 10.2 & 700 \\
\hline HTS1 & 190 & 1555.4 & 0.767 & 9.0 & 12.0 & 981 \\
\hline HTS2 & 106 & 1571.0 & 0.847 & 7.5 & 12.0 & 820 \\
\hline LTS & 250 & 3000.0 & 0.419 & 10.0 & 12.0 & 600 \\
\hline PROX & 300 & 2057.1 & 0.814 & 16.5 & 12.0 & 1801 \\
\hline
\end{tabular}
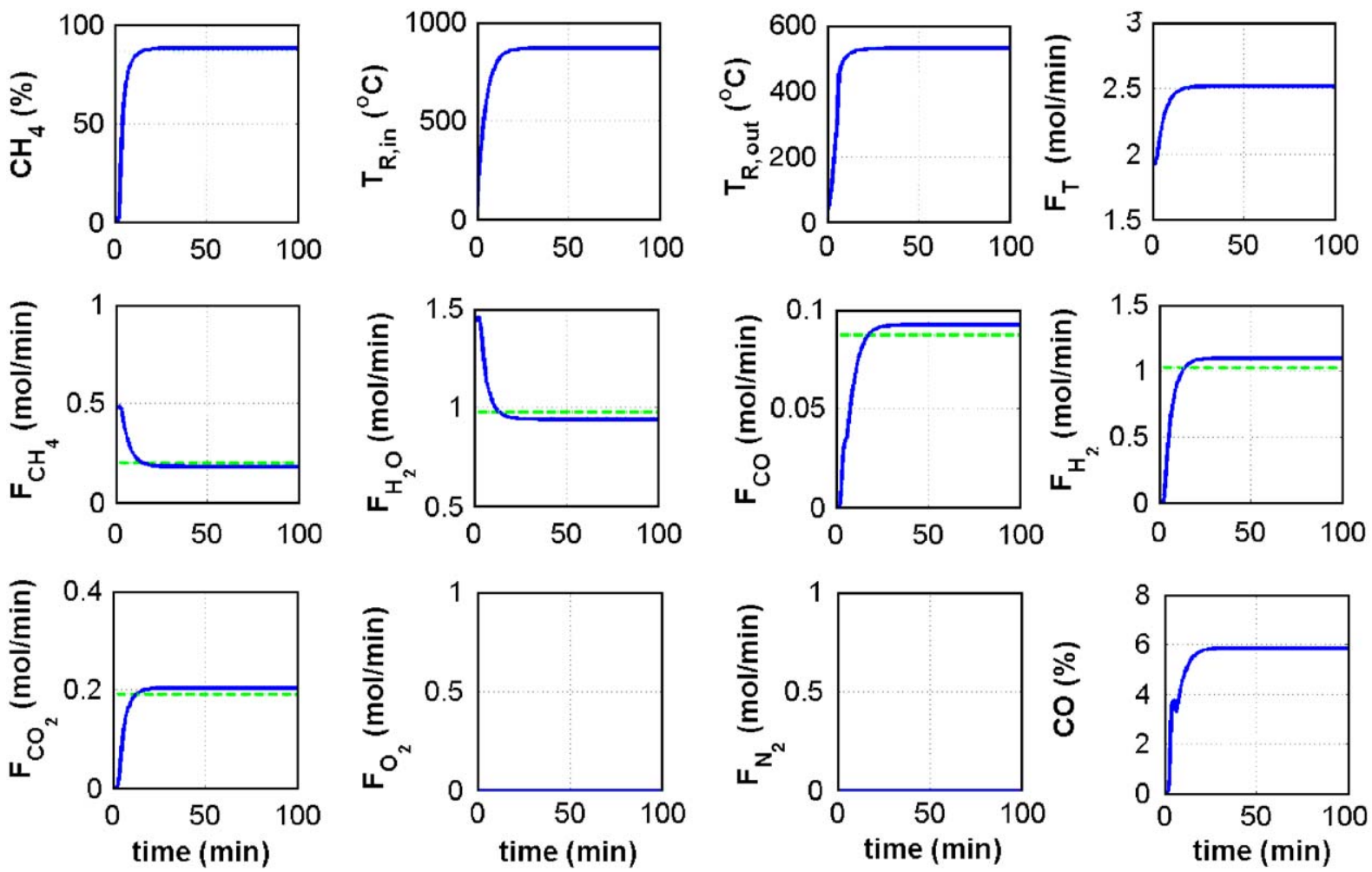

Fig. 4. Start-up dynamics for the SR pathway form dynamic simulation showing all flow rates and compositions at the outlet stream of the reformer.

corresponds to the fuel processor with a maximum efficiency of $68.4 \%$ [14].

\subsection{Parameter fitting}

In order to describe the temperature and composition dynamics, it is necessary to modify some of the model parameters in the dynamic model (Eqs. (1-6)). Because the honeycomb catalyst is quite complex and enormous, instead of modeling the honeycomb details, the heat capacity of the solid carrier (Eq. (1)) was adjusted to meet the dynamic trajectory of the reformer outlet temperature. Similarly, for the composition profiles, the gas holdup in the reformer was also adjusted to meet the dynamic trajectory of the composition of each component. From the process dynamics point of view, this is similar to adjusting the time constant of a transfer function which should be effective to obtain dynamical behavior description. Thus, the dynamic modeling of the fuel processor consists of the following steps:

1. Obtain feed condition and the heat input $\left(Q_{\mathrm{F}}\right)$ to the burner.

2. Adjust $C_{P \mathrm{~S}}, W_{\mathrm{S}, n}$ (Eq. (1)) to meet the dynamic trajectory of the reformer inlet temperature.

3. Adjust $\rho_{\mathrm{av}} V_{\mathrm{R}, n}$ to meet the dynamic trajectory of the conversion of $\mathrm{CH}_{4}$ and $\mathrm{CO}$ concentration out of the reformer.

4. Adjust the $m_{\mathrm{w}, n} C_{P_{\mathrm{w}, n}}$ of the metal reactor wall to find the dynamic trajectory reactor wall temperature. 
Fig. 3 shows the ATR pathway start-up trajectories of the reformer inlet temperature, molar flow rate of each component, $\mathrm{CO}$ concentration and the conversion of $\mathrm{CH}_{4}$ predicted by the modified dynamic model. The simulation results give good behavior description of the experimental data given by UCL of ITRI. The reformer inlet temperature and outlet flow rate of each component predicted by the dynamic model were practically the same as that of the experiment. The steady-state offset in the reformer outlet temperature comes from the mismatches between temperature and composition profiles [14], which can be the results of the heat loss which was unaccounted for. Table 4 gives the heat capacities, solid and gas holdup in the fuel processor from the regression. In the experiment, the reformer switches to the SR pathway after the ATR start-up, so no start-up experimental data were available for the SR pathway. However, the dynamic model enables us to study the dynamics with the SR start-up. Fig. 4 reveals that, as expected, the dynamic responses for the SR pathway are slower than that of the ATR pathway because of higher reaction temperature and endothermic nature of the reaction mechanism.

Due to the lack of complete information for the dynamic behavior of the gas cleaning unit, we scale the dynamic of each reactor proportional to the size of the reactors. So the dynamic models of HTS1, HTS2, LTS and PROX were also set up to explore dynamics and control of the fuel processor.
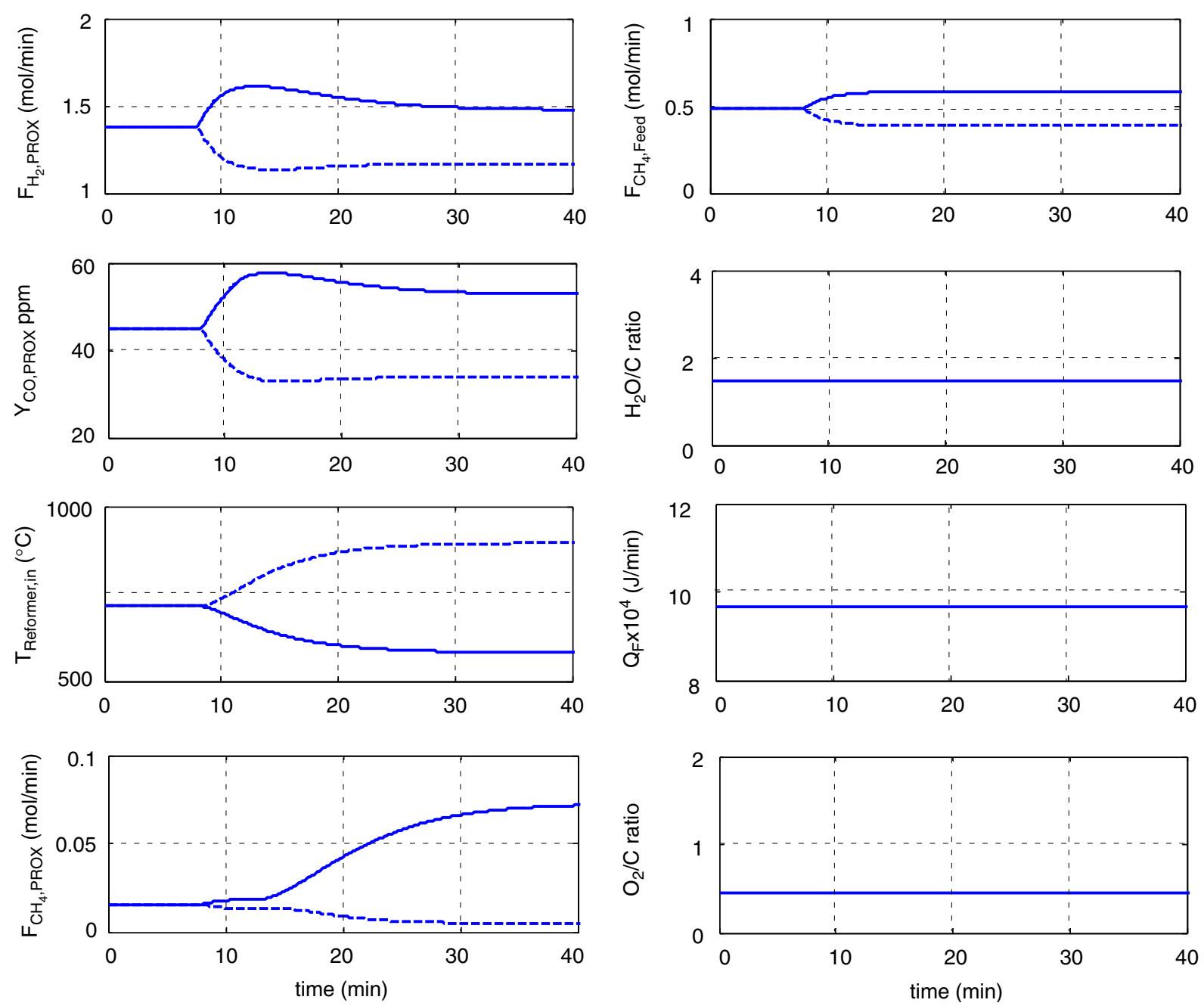

Fig. 5. Open-loop dynamic responses for $\pm 20 \%$ changes of $\mathrm{CH}_{4}$ feed flow rate (solid line for $+20 \%$ increase and dashed line for $-20 \%$ change). 

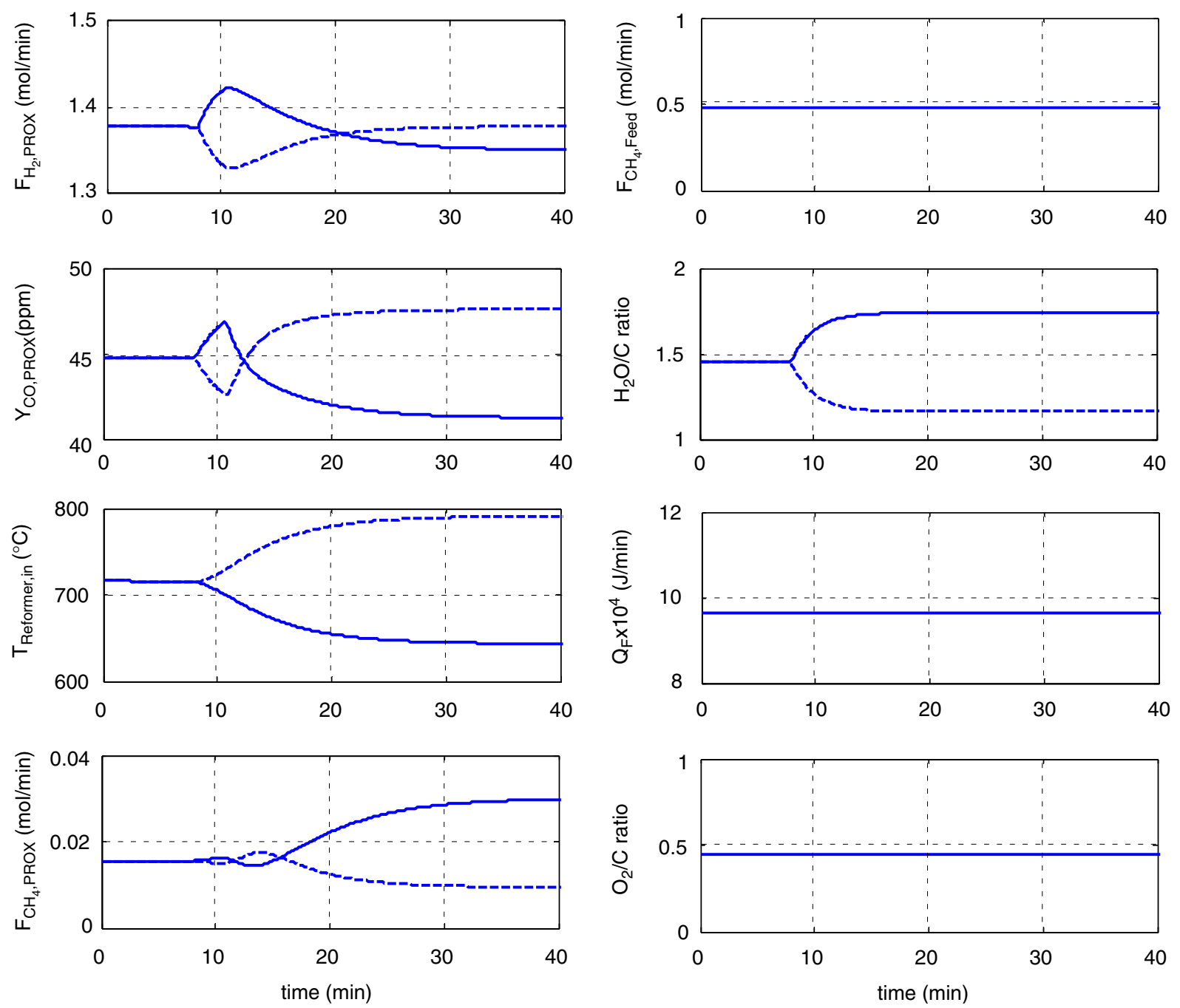

Fig. 6. Open-loop dynamic responses for $\pm 20 \%$ changes of $\mathrm{H}_{2} \mathrm{O} / \mathrm{CH}_{4}$ feed ratio (solid line for $+20 \%$ increase and dashed line for $-20 \%$ change).

\section{Steady-state and dynamical sensitivities}

The effects of process variables to the operation of the fuel processor are explored here. Important process variables include $\mathrm{CH}_{4}$ feed flow rate, $\mathrm{H}_{2} \mathrm{O} / \mathrm{CH}_{4}$ feed ratio, $\mathrm{O}_{2} / \mathrm{CH}_{4}$ feed ratio and the reformer inlet temperature $T_{\text {in }}$. The $\mathrm{H}_{2} \mathrm{O} / \mathrm{CH}_{4}$ feed ratio and $\mathrm{O}_{2} / \mathrm{CH}_{4}$ feed ratio used here denote the ratio of two corresponding feed streams into the reformer (Fig. 1). Here, we are interested in the steady state as well as dynamic aspects of these sensitivities. Note that the simulations were carried out for the entire fuel processor system, including reformer, HTS1, HTS2, LTS and PROX reactors (Fig. 2).

Open-loop step changes were made to explore the effects of these manipulated variables. Fig. 5 presents dynamic responses for $\pm 20 \%$ changes in $\mathrm{CH}_{4}$ feed flow rate at $t=8 \mathrm{~m}$, when the $\mathrm{H}_{2} \mathrm{O} / \mathrm{CH}_{4}$ feed ratio $\mathrm{O}_{2} / \mathrm{CH}_{4}$ feed ratio and the heat input to the burner $\left(Q_{\mathrm{F}}\right)$ were kept constant. Fig. 5 also shows that when the $\mathrm{CH}_{4}$ feed flow rate increases by $20 \%$, the $\mathrm{H}_{2}$ production rate goes through a fast increase and then reaches a steady state with a $10 \%$ increase in the $\mathrm{H}_{2}$ yield. The reformer inlet temperature $\left(T_{\text {in }}\right)$ also decreases due to the fact that the heat input $Q_{\mathrm{F}}$ remains unchanged. The $\mathrm{CO}$ concentration also increases by a factor which is similar to that of the $\mathrm{H}_{2}$ production rate. The opposite behavior was observed for a negative change in the $\mathrm{CH}_{4}$ feed flow rate and nonlinear responses were observed.

Fig. 6 presents the open-loop responses for $\pm 20 \%$ changes in $\mathrm{H}_{2} \mathrm{O} / \mathrm{CH}_{4}$ feed ratio, while keeping the $\mathrm{CH}_{4}$ feed flow rate, $\mathrm{O}_{2} / \mathrm{CH}_{4}$ feed ratio and $Q_{\mathrm{F}}$ constant. As the $\mathrm{H}_{2} \mathrm{O} / \mathrm{CH}_{4}$ feed ratio increases, the $\mathrm{H}_{2}$ production rate goes through an increase followed by a decrease. How- 

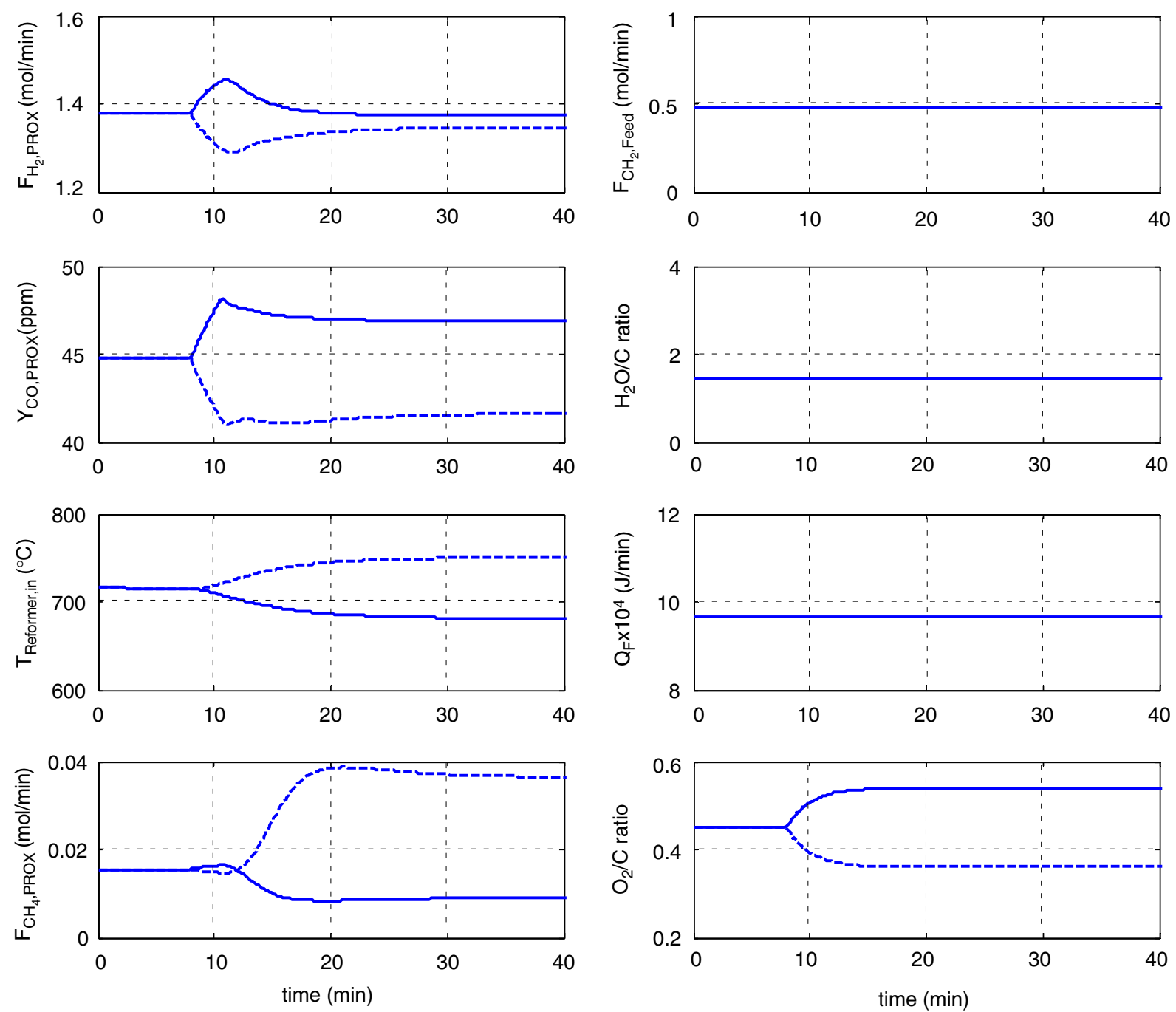

Fig. 7. Open-loop dynamic responses for $\pm 20 \%$ changes of $\mathrm{O}_{2} / \mathrm{CH}_{4}$ feed ratio (solid line for $+20 \%$ increase and dashed line for $-20 \%$ change).

ever, the $\mathrm{H}_{2}$ production rate is relatively insensitive to the $\mathrm{H}_{2} \mathrm{O} / \mathrm{CH}_{4}$ ratio change (cf. Figs. 5 and 6). Fig. 6 also gives the dynamic response of the $\mathrm{CO}$ concentration. In comparison, the dynamic responses of $\mathrm{H}_{2} \mathrm{O} / \mathrm{CH}_{4}$ feed ratio change were faster than that of the $\mathrm{CH}_{4}$ feed flow rate, because only feed water flow rate was changed for the former case, while both $\mathrm{CH}_{4}$ feed flow and water feed flow were varied in the later one.

Fig. 7 shows the open-loop responses for $\pm 20 \%$ change in $\mathrm{O}_{2} / \mathrm{CH}_{4}$ feed ratio. Similar to the case of $\mathrm{CH}_{4}$ feed rate change, the $\mathrm{H}_{2}$ production rate shows an increase, but only by $5 \%$. The $\mathrm{CO}$ concentration also shows a small increase for an $\mathrm{O}_{2} / \mathrm{CH}_{4}$ feed ratio increase. The speed of response is similar to that of $\mathrm{H}_{2} \mathrm{O} / \mathrm{CH}_{4}$ feed ratio change.
The ongoing analysis indicates that the $\mathrm{CH}_{4}$ flow rate is an important manipulated variable to handle $\mathrm{H}_{2}$ production rate variation as compared to $\mathrm{H}_{2} \mathrm{O} / \mathrm{CH}_{4}$ and $\mathrm{O}_{2} / \mathrm{CH}_{4}$ feed ratios. Either $\mathrm{H}_{2} \mathrm{O} / \mathrm{CH}_{4}$ or $\mathrm{O}_{2} / \mathrm{CH}_{4}$ can be used to maintain a safe $\mathrm{CO}$ concentration while showing little impact on $\mathrm{H}_{2}$ production rate. Finally, instead of fixing the $Q_{\mathrm{F}}$, the reformer inlet temperature should be controlled at a constant value to prevent temperature constraint violation.

\section{Control structure design}

In order to accommodate the load changes in a PEMFC, the hydrogen flow rate from the fuel processor should be adjusted to satisfy the power demand. The control objective 


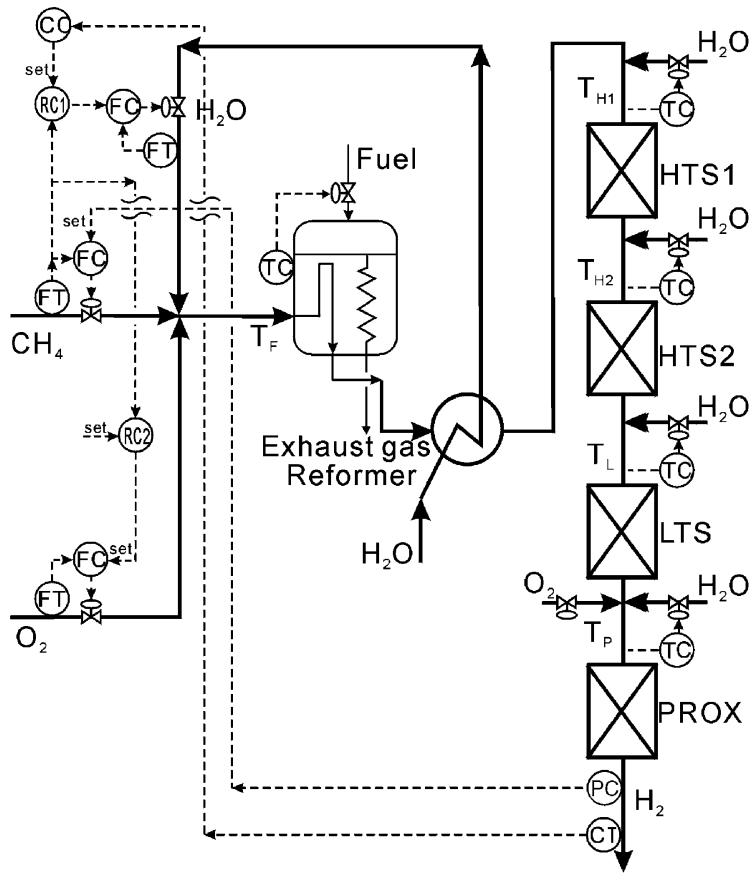

Fig. 8. On-supply control structure (CS1).

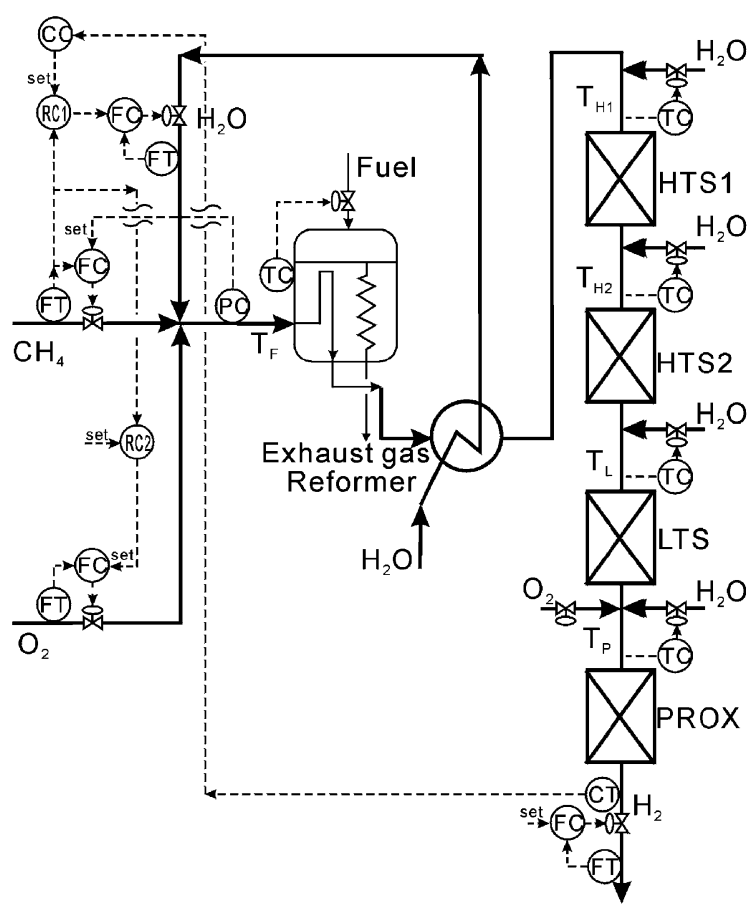

Fig. 9. On-demand control structure (CS2).

of the fuel processor is to provide smooth $\mathrm{H}_{2}$ production rate changes while keeping the $\mathrm{CO}$ concentration at a safe level such that the $\mathrm{CO}$ concentration will not poison the catalyst of PEMFC. We would like to achieve the objective with the simplest possible control structure. Two control structures were studied. The first control structure uses the methane feed flow rate as the throughput manipulator (TPM) which is denoted as the on-supply control structure (CS1) [16-19]. The other control structure uses the hydrogen production rate as the throughput manipulator, denoted as the on-demand control structure (CS2) hereafter.

\subsection{On-supply control structure (CS1)}

The open-loop tests clearly indicate that the $\mathrm{CH}_{4}$ feed flow rate is effective in handling $\mathrm{H}_{2}$ production rate variation. Thus, the $\mathrm{CH}_{4}$ feed flow is a good candidate for the TPM. However, it is less obvious that which one of two ratios, $\mathrm{H}_{2} \mathrm{O} / \mathrm{CH}_{4}$ or $\mathrm{O}_{2} / \mathrm{CH}_{4}$, should be used to maintain the $\mathrm{CO}$ concentration. In this work, the $\mathrm{H}_{2} \mathrm{O} / \mathrm{CH}_{4}$ ratio is selected. The CS1 control structure has the following loops:

1. Use the $\mathrm{CH}_{4}$ feed flow rate as the throughput manipulator.

2. Maintain the fuel processor outlet pressure by changing the $\mathrm{CH}_{4}$ feed flow rate.

3. Use the $\mathrm{H}_{2} \mathrm{O} / \mathrm{CH}_{4}$ feed ratio to control the $\mathrm{CO}$ concentration.

4. Keep the reformer inlet temperature constant by adjusting the energy supply.

5. Control the HTS1, HTS2, LTS and PROX inlet temperatures by changing the $\mathrm{H}_{2} \mathrm{O}$ addition.

6. Fix the $\mathrm{O}_{2} / \mathrm{CH}_{4}$ feed ratio via a ratio control.

Fig. 8 shows the CS1 with one pressure loop, one temperature loop, one composition loop, two ratio controllers, three flow controllers and four temperature controllers for the water addition. In the dynamic simulation, a thirdorder lag with a time constant of $0.1 \mathrm{~min}$ is assumed for the composition analyzer. The relay feedback test [20] is used to find the ultimate gain $\left(K_{\mathrm{u}}\right)$ and ultimate period $\left(P_{\mathrm{u}}\right)$. Then, the Tyreus and Luyben [21] tuning rule is employed to find the controller gain and the reset time for PI controllers.

\subsection{On-demand control structure (CS2)}

The on-demand control structure differs from CS1 in that the $\mathrm{H}_{2}$ production rate is adjusted directly by the downstream demand. A change in the $\mathrm{H}_{2}$ production rate leads to a variation in the system pressure and, subsequently, the $\mathrm{CH}_{4}$ feed flow is changed. Therefore, the CS2 control structure consists of the following loops:

1. $\mathrm{H}_{2}$ production rate is under flow control.

2. $\mathrm{CH}_{4}$ feed flow rate is adjusted by the reformer pressure controller.

3. $\mathrm{H}_{2} \mathrm{O}$ flow rate is ratio to the $\mathrm{CH}_{4}$ flow rate via $\mathrm{RC} 1$.

4. $\mathrm{O}_{2}$ flow rate is ratio to the $\mathrm{CH}_{4}$ flow rate via $\mathrm{RC} 2$.

5. $\mathrm{H}_{2} \mathrm{O} / \mathrm{CH}_{4}$ feed ratio is adjusted by the $\mathrm{CO}_{2}$ concentration. 

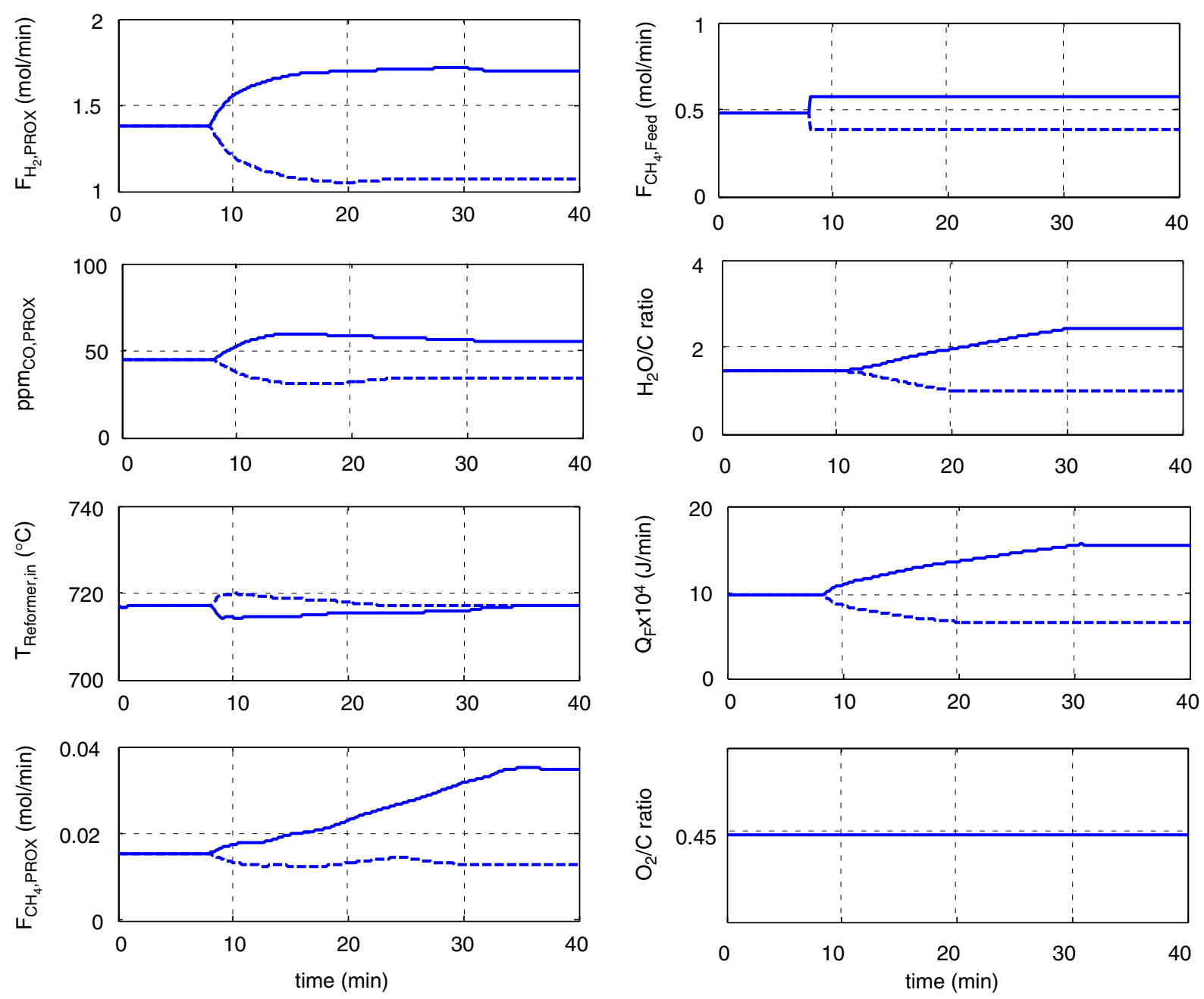

Fig. 10. Closed-loop responses for $\pm 20 \% \mathrm{H}_{2}$ production rate changes using CS1 with CO composition control (solid line for $+20 \%$ increase and dashed line for $-20 \%$ change).

6. Reformer inlet temperature is maintained by changing the fuel flow rate.

Fig. 9 show the CS2 control with one temperature loop, one composition loop, two ratio loops, four flow loops and three temperature loops for $\mathrm{H}_{2} \mathrm{O}$ addition. The controller design follows the same steps as that of the CS1.

\subsection{Results}

Consider the case of $\pm 20 \%$ changes in the $\mathrm{H}_{2}$ production rate. Fig. 10 shows the $\mathrm{CH}_{4}$ feed rate goes through step changes while the $\mathrm{H}_{2}$ production rate $\left(F_{\mathrm{H}_{2}}\right.$,PROX $)$ shows a first-order type of response and it takes approximately $10 \mathrm{~min}$. to reach the new steady state. However, the entire composition profiles do not settle until $35 \mathrm{~min}$. for the production rate increase. Fig. 10 also reveals that the $\mathrm{H}_{2} \mathrm{O} / \mathrm{CH}_{4}$ ratio is adjusted to bring the $\mathrm{CO}$ concentration back to the set point, and this is the result of the composition control. Because of the low sensitivity between the $\mathrm{H}_{2} \mathrm{O} / \mathrm{CH}_{4}$ ratio, and $\mathrm{CO}$ concentration, it is likely to eliminate the composition controller without violating the $\mathrm{CO}$ concentration constraint.

Fig. 11 shows the closed-loop responses without the composition controller, i.e. the $\mathrm{H}_{2} \mathrm{O} / \mathrm{CH}_{4}$ ratio is fixed at the nominal value. Results indicate that we have quite similar dynamics in the $\mathrm{H}_{2}$ production rate and the $\mathrm{CO}$ concentration reaches $60 \mathrm{ppm}$ for a $20 \%$ feed rate increase. Furthermore, all the dynamics settle in $10 \mathrm{~min}$, which is faster than the previous case (Fig. 10). From the control complexity, fast transition and constraint violation points of view, it is clear that the $\mathrm{CO}$ composition control cannot be necessary and it is eliminated for the subsequent development.

The on-demand control structure (CS2 in Fig. 9) is explored next. Fig. 12 shows that a very fast transition in the $\mathrm{H}_{2}$ production is observed (with closed-loop time con- 

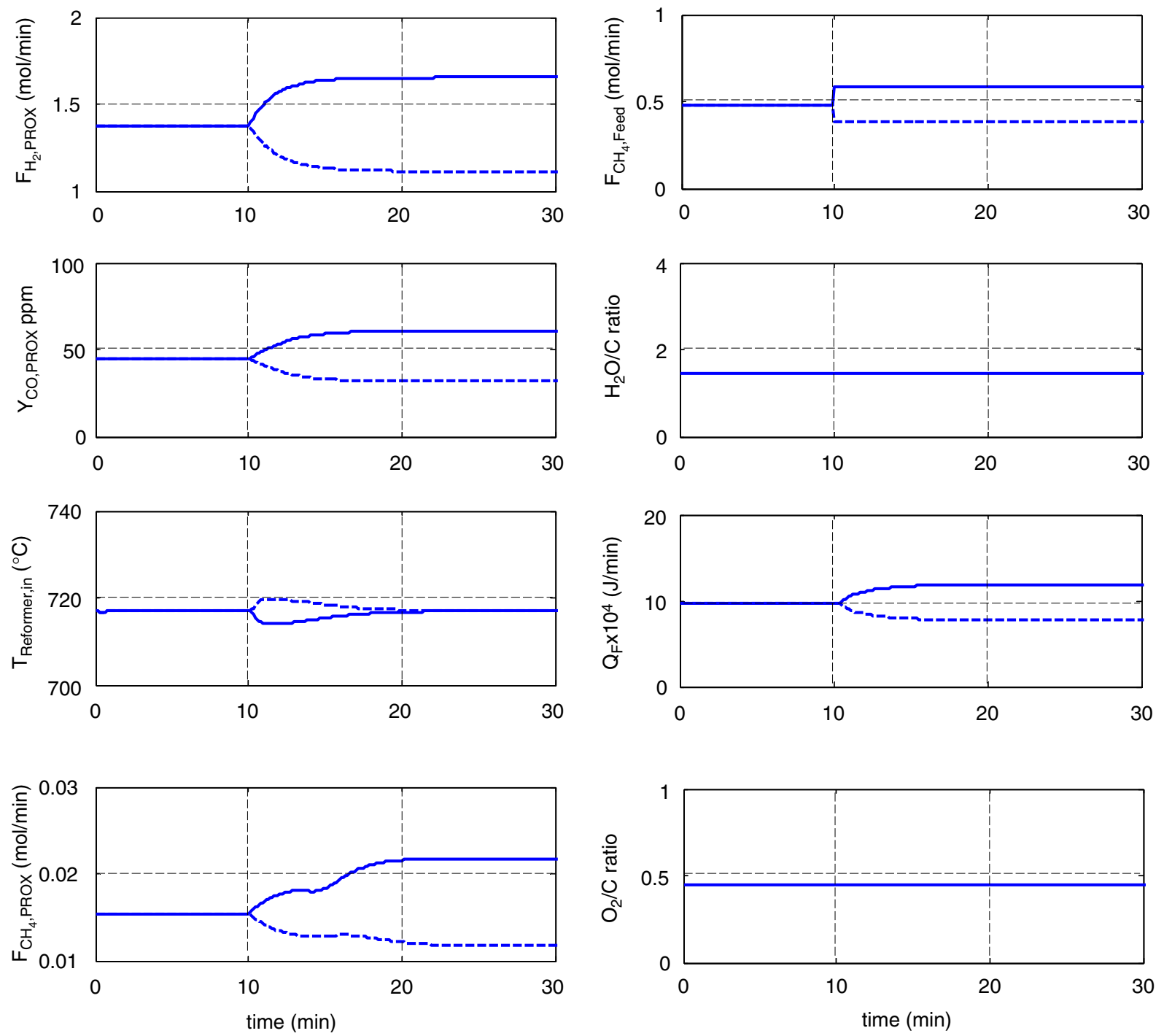

Fig. 11. Closed-loop responses for $\pm 20 \% \mathrm{H}_{2}$ production rate changes using CS1 without CO composition control (solid line for $+20 \%$ increase and dashed line for $-20 \%$ change).

stant approximately equal to $2 \mathrm{~min}$ ) without $\mathrm{CO}$ constraint violation. Tight reformer inlet temperature control can be achieved. But for a $20 \%$ decrease in the $\mathrm{H}_{2}$ production rate, the temperature exceeds $720^{\circ} \mathrm{C}$ monoterary and then back to the set point. Comparing Fig. 12 to Fig. 11, it is obvious that the CS2 is a much better control structure to handle production rate variation, which is one of the most important disturbances for the fuel processor.

\section{Conclusions}

A systematical approach is proposed to model the dynamic responses of an experimental fuel process. Reasonable behavior description can be obtained by adjusting model parameters. Then, the control issue was addressed. The control objective of a fuel processing system is quite clear: provide responsiveness to the changes in hydrogen demand while keeping the carbon monoxide concentration below $100 \mathrm{ppm}$. Two control structures are proposed. One uses the fuel feed flow rate as the throughput manipulator (TPM), which was called the on-supply structure (CS1), and the other uses the reactor outlet flow as the TPM, which was called the on-demand structure (CS2). In both control structures, reasonable control can be obtained while maintaining the $\mathrm{CO}$ at allowable level. Moreover, the composition control can be eliminated without possible constraint violation. Judging on the speed of response, the on-demand control structure (CS2) is an ideal candidate to provide rapid transition for load changes. 

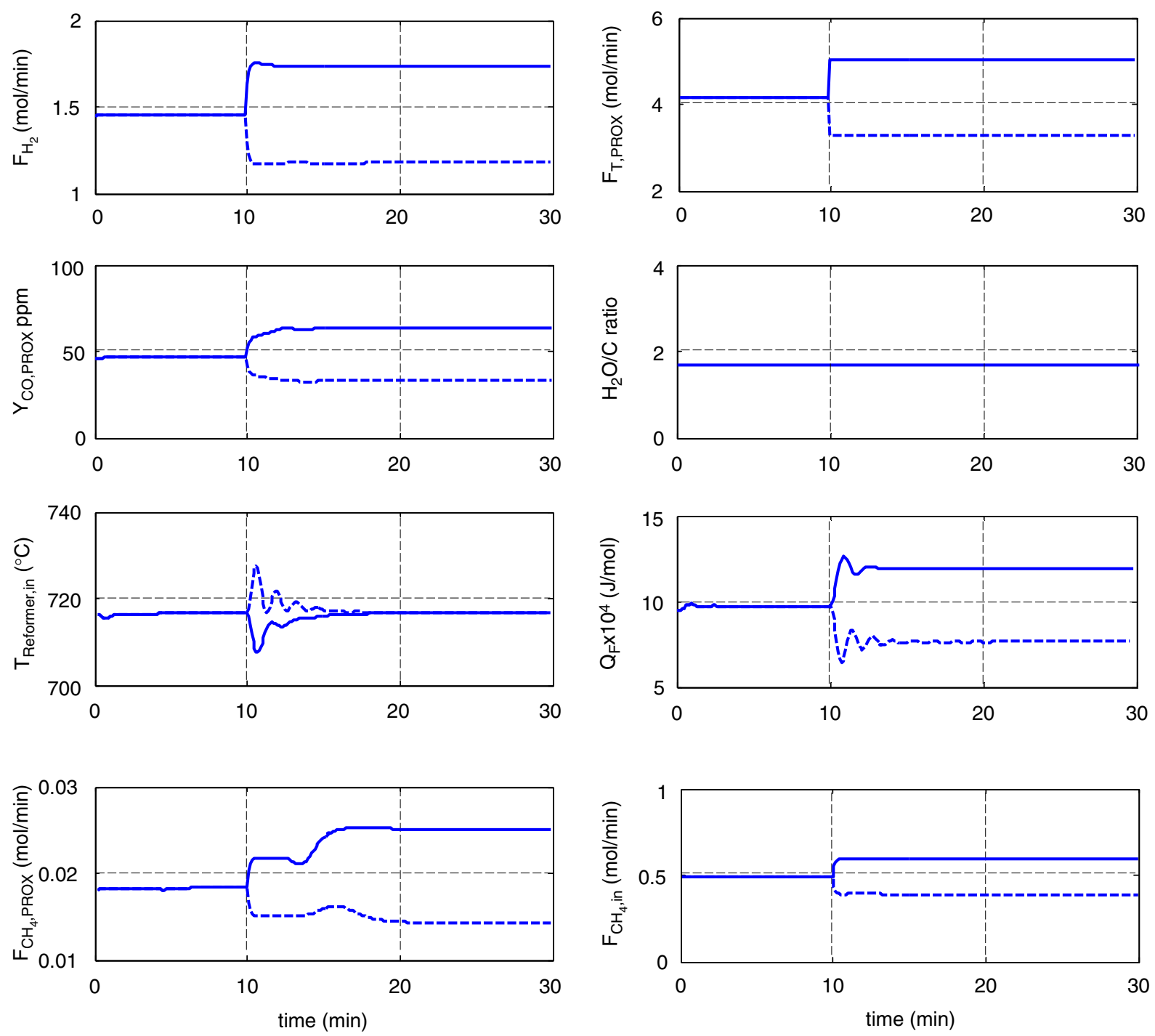

Fig. 12. Closed-loop responses for $\pm 20 \% \mathrm{H}_{2}$ production rate changes using CS2 without $\mathrm{CO}$ composition control (solid line for $+20 \%$ increase and dashed line for $-20 \%$ change).

\section{References}

[1] Ahmed S, Krumpelt M. Hydrogen from hydrocarbon fuels for fuel cells. Int J Hydrogen Energy 2001;26:291-301.

[2] Fuel cell handbook, EG\&G Services Parsons, Inc. Science Applications International Corporation; 2000.

[3] Larminie J, Dicks AL. Fuel cell systems explained. New York: Wiley; 2000.

[4] Hirschenhofer JH, Stauffer DB, Engleman RR, Klett MG. Fuel cell handbook, 4th ed., DOE/FETC-99/1076, Morgantown, WV: US Department of Energy, Federal Energy Technology Center, 1998.

[5] Song C. Fuel processing for low-temperature and hightemperature fuel cells. challenges, and opportunities for sustainable development in the 21st century. Catal Today 2002;77:17-49.
[6] Farrauto RJ, Heck RM. Environmental catalysis into the 21st century. Catal Today 2000;55:179-87.

[7] de Smet CRH, de Croon MHJ, Berger MRJ, Marin GB, Schouten JC. Design of adiabatic fixed-bed reactors for the partial oxidation of methane to synthesis gas. Application to production of methanol and hydrogen-for-fuel-cells. Chem Eng Sci 2001;56:4849-61.

[8] Doss ED, Kumar R, Ahluwalia RK, Krumpelt M. Fuel processors for automotive fuel cell systems: a parametric analysis. J Power Sources 2001;102:1-15.

[9] Choi Y, Stenger HG. Kinetics, simulation and insights for CO selective oxidation in fuel cell applications. J Power Sources 2004;129:246-54.

[10] Lattner JR, Harold MP. Comparison of conventional and membrane reactor fuel processors for hydrocarbon-based PEM fuel cell systems. Int J Hydrogen Energy 2004;29:393-417. 
[11] Beckhaus P, Heinzel A, Mathiak J, Roes J. Dynamics of $\mathrm{H}_{2}$ production by steam reforming. $\mathrm{J}$ Power Sources 2004;127:294-9.

[12] Sommer M, Lamm A, Docter A, Agar D. Modelling and dynamic simulation of a fuel cell system with an autothermal gasoline reformer. J Power Sources 2004;127:313-8.

[13] Springmann S, Bohnet M, Docter A, Lammd A, Eigenberger G. Cold start simulations of a gasoline based fuel processor for mobile fuel cell applications. J Power Sources 2004;128: $13-24$.

[14] Lin ST, Chen YH, Yu CC, Liu YC, Lee CH. Modeling of an experimental fuel processor. J Power Sources, in press.

[15] Reyes F, Luyben WL. Steady-state and dynamic effects of design alternatives in heat-exchanger/furnace/reactor processes. Ind Eng Chem Res 2000;39:3335-46.
[16] Luyben WL, Tyreus BD, Luyben ML. Plantwide process control. New York: McGraw-Hill; 1999.

[17] Chen YH, Yu CC. Design and control of heat-integrated reactors. Ind Eng Chem Res 2003;42:2791-808.

[18] Cheng YC, Wu KL, Yu CC. Arrangement of throughput manipulator and inventory control in plantwide control. J Chin Inst Chem Eng 2002;33:283.

[19] Cheng YC, Yu CC. Optimal region for design and control of ternary systems. AIChE J 2003;49:682-705.

[20] Yu CC. Autotuning of PID controllers. London: Springer; 1999.

[21] Tyreus BD, Luyben WL. Tuning PI controllers for integratordead time processes. Ind Eng Chem Res 1992;35:3480. 